\title{
Upaya Meningkatkan Hasil Belajar Siswa Kelas IX melalui Model Pembelajaran Kooperatif Tipe STAD pada Konsep IPA
}

\author{
Disubmit 7 Juli 2021, Direvisi 20 Agustus 2021, Diterima 30 Agustus 2021 \\ Melis Mardianis ${ }^{1}$ \\ ${ }^{1}$ SMP Negeri 1 Citeureup, Kabupaten Bogor, Indonesia \\ Email Korespondensi: minaminah02@gmail.com
}

\begin{abstract}
Abstrak
Tujuan penelitian ini untuk mengetahui peningkatkan hasil belajar IPA melalui penerapan model pembelajaran kooperatif tipe STAD. Penelitian ini merupakan penelitian tindakan kelas. Setiap siklus teridiri dari planning, action, observation, dan reflection. Subjek penelitian dalam penelitian ini adalah 36 siswa kelas IX di salah satu SMP Negeri di Kabupaten Bogoe, Indonesia. Hasil penelitian menunjukkan terjadi peningkatan nilai rata-rata siswa dari siklus I sebesar $61 \%$ menjadi $80 \%$ pada siklus II. Persentase skor rata-rata aktivitas kelompok pada siklus I adalah $56 \%$ menjadi $100 \%$ pada siklus II. Nilai keaktifan siswa pada siklus I adalah $60 \%$ menjadi $94 \%$ pada siklus II. Berdasarkan hasil pengamatan observer, presentase kreativitas guru pada siklus I adalah $78 \%$ menjadi 95\% pada siklus II. Dapat disimpulkan bahwa pembelajaran kooperatif tipe STAD dapat meningkatkan hasil belajar IPA dan aktivitas belajar siswa. Adapun beberapa saran yang perlu dilakukan oleh seorang guru untuk meningkatkan kemampuannya dalam menggunakan pembelajaran kooperatif tipe STAD, diantaranya melakukan perencanaan dan persiapan pembelajaran sebelum melakukan pembelajaran, memberikan pelayanan kepada siswa secara optimal, menguasai materi pembelajaran dengan sebaik-baiknya, memberikan pelayanan secara personal atau klasikal secara terpadu, menggunakan alat peraga agar siswa tertarik dalam mengikuti proses pembelajaran, dan memberikan remedial dan pengayaan, serta mengaitkan pembelajaran dengan kehidupan siswa sehari-hari.
\end{abstract}

Kata Kunci: hasil belajar, STAD, IPA

\section{PENDAHULUAN}

Proses belajar dan mengajar ilmu sains atau IPA di dalam kelas perlu diperhatikan secara mendalam (Prasetyowati, 2014; Widodo, 2017). Pembelajaran di sekolah perlu mewujudkan pembelajaran yang efektif (Hanafy, 2014). Akan tetapi, hasil pengamatan awal peneliti pada pembelajaran IPA di kelas IX di salah satu SMP Negeri di Kabupaten Bogor di Indonesia belum sesuai dengan pembelajaran yang diharapkan. Permasalahan-permasalahan yang terlihat bahwa siswa kurang antusias untuk belajar. Terlihat siswa mangalami kejenuhan dalam belajar. Hal ini menjadi gambaran bahwa minat belajar IPA siswa kurang dan berakibat pada hasil belajar IPA yang masih rendah.

STAD merupakan singkatan dari Student Team Achievement Division dengan proses awal dimulai dengan pembuatan kelompok secara heterogen (Slavin, 2005). Dalam prosesnya, model pembelajaran kooperatif tipe STAD menekankan kepada guru untuk berusaha agar siswa dapat belajar dalam kelompok dengan baik, yaitu dengan cara memberikan motivasi kepada siswa untuk mencapai keberhasilan belajar siswa secara berkelompok dan individu dengan saling berinteraksi dalam kelompoknya (Slavin, 2005). 
Berdasarkan pemaparan tersebut, tujuan dari penelitian ini adalah untuk menginvestigasi peningkatan hasil belajar siswa pada mata pelajaran IPA di kelas IX melalui model pembelajaran kooperatif tipe STAD.

\section{METODE}

Penelitian tindakan kelas digunakan dalam penelitian ini yang terdiri atas perencanaan, tindakan, pengamatan, refleksi (Wibawa, 2003). Subjek dalam penelitian ini adalah 36 siswa kelas IX.di salah satu SMP Negeri di Kabupaten Bogor, Indonesia. Penelitian yang dilakukan dilakukan dengan tahap pertama yaitu perencanaan dengan mempersiapkan rencana pelaksanaan pembelajaran (RPP), media pembelajaran, instrumen seperti soal pre-test dan posttest, dan lembar pengamatan. Tahap kedua yaitu pelaksanaan tindakan (action), dimana peneliti melakukan proses tindakan menggunakan segala sesuatu hal yang sudah disiapkan di tahap pertama. Tahap ketiga adalah pengamatan proses tindakan. Tahap akhir adalah refleksi, dimana tahap ini sangat penting untuk kelanjutan siklus kedua. Tahapaan akhir ini menentukan dalam hal perbaikan apa-apa saja yang kurang di siklus pertama (Wiriaatmadja, 2014).

\section{HASIL DAN PEMBAHASAN}

Berdasarkan pengamatan pada siklus I ini dapat terlihat bahwa sebagian besar siswa belum memahami pembelajaran materi Listrik Dinamis. Pada penelitian ini dapat dikumpulkan data penilaian harian siswa setelah siklus I dilaksanakan. Berdasarkan perolehan hasil evaluasi dan observasi dengan nilai kriteria ketuntasan minimum (KKM) sebesar 75; nilai individual baru mencapai ketuntasan 61\%, nilai kelompok baru mencapai ketuntasan 56\%, nilai keaktifan siswa baru mencapai ketuntasan 69\%, dan nilai kreativitas guru baru mencapai $78 \%$.

Berdasarkan hasil pengamatan, siswa kelas IX masih terbiasa dengan pembelajaran yang hanya mengacu pada buku dan sangat jarang sekali terjadi diskusi ketika tidak ada instruksi dari guru. Dalam pembelajaran ini, siswa dibiasakan untuk melakukan diskusi perkelompok, dengan pembagian kelompok. Dalam penelitian ini, kelompok yang dibuat dikelompokkan berdasarkan heterogen di bidang akademik (tinggi, sedang, dan rendah). Diskusi kelompok dalam kondisi heterogen membuat siswa yang memiliki nilai akademik sedang dan rendah termotivasi oleh siswa yang memiliki nilai akademik tinggi. Keadaan ini menganut pada teori social constructivism, yaitu proses belajar berasal dari pertukaran ide dan informasi dalam diskusi, sehingga membuat pembelajaran menjadi bermakna. Social constructivism merupakan salah satu teori belajar constructivism, dimana siswa sudah 
memiliki pengetahuan di awal dan diperkuat oleh pengetahuan yang di dapat dari hasil diskusi (Vygotsky, 1978).

Berdasarkan hasil sebaran distribusi data nilai individual, nilai kelompok, nilai keaktifan siswa dan nilai kreativitas Guru belum mencapai ketuntasan lebih dari $85 \%$ untuk itu perlu diadakan penelitian ke siklus berikutnya (Siklus II). Berikut ini hasil pengamatan yang dilaksanakan pada Penelitian Tindakan Kelas pada siklus II.

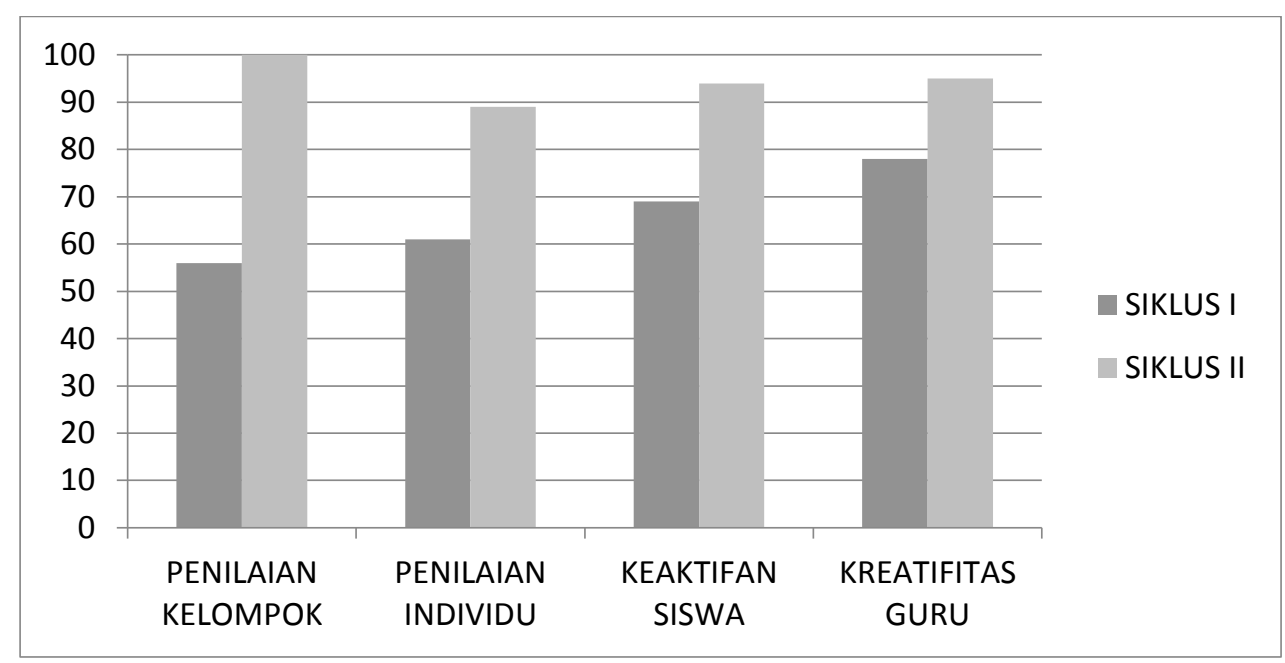

Gambar 1. Perbandingan penilaian Siswa dan Guru pada Siklus 1 dan 2

Perolehan hasil nilai, dapat dilihat pencapaian hasil belajar siswa pada siklus II diantaranya; nilai individual baru mencapai ketuntasan 89\%, nilai kelompok baru mencapai ketuntasan $100 \%$, nilai keaktifan siswa baru mencapai ketuntasan 94\%, dan nilai kreativitas guru baru mencapai 95\%. Adapun perbandingan nilai-nilai tersebut disajikan pada Gambar 1, sedangkan peningkatannya dapat dilihat pada Tabel 1.

Tabel 1. Peningkatan Nilai Siswa pada Siklus I dengan Siklus II

\begin{tabular}{llccc}
\hline No & \multicolumn{1}{c}{ Penilaian } & Siklus I & Siklus II & Peningkatan \\
\hline 1 & Nilai Individual & $61 \%$ & $89 \%$ & $28 \%$ \\
2 & Nilai Kelompok & $56 \%$ & $100 \%$ & $44 \%$ \\
3 & Nilai Keaktifan Siswa & $69 \%$ & $94 \%$ & $25 \%$ \\
4 & Nilai Kreatifitas Guru & $78 \%$ & $95 \%$ & $17 \%$ \\
\hline
\end{tabular}

Terjadi peningkatan pada nilai individu, kelompok, keaktifan siswa, dan kreatifitas guru. Nilai individu di ambil dari hasil evaluasi di akhir siklus, nilai kelompok diambil dari hasil kerja kelompok siswa dalam proses pembelajaran. Nilai keaktifan siswa diambil dari hasil observasi pada saat proses pembelajaran dari awal sampai akhir. Nilai kreatifitas guru diambil dari hasil refleksi, dimana guru melakukan modifikasi di saat terjadi gangguan atau kendala dalam proses pembelajaran, misalnya masalah waktu, kegiatan ektrakulikuler, dan lain-lain. 
Berdasarkan perolehan hasil nilai pada siklus I dan siklus II, dapat dilihat pencapaian hasil belajar siswa baik secara individual, kelompok dan juga penilaian keaktifan serta kreatifitas guru terdapat peningkatan serta mencapai ketuntasan sudah lebih dari $85 \%$. Berdasarkan temuan tersebut, dapat diketahui bahwa model pembelajaran kooperatif tipe STAD dapat meningkatkan hasil belajar siswa kelas IX pada mata pelajaran IPA. Peningkatan untuk nilai individual mencapai $28 \%$, peningkatan untuk nilai kelompok mencapai $44 \%$, peningkatan untuk nilai keaktifan siswa mencapai 25\%, dan meningkatan untuk nilai kreativitas guru mencapai 17\%. Hal ini sejalan dengan penelitian Sudana \& Wesnawa (2017) yang juga melakukan penerapan model pembelajaran kooperatif tipe STAD dapat menignkatkan hasil belajar IPA dengan peningkatan sebesar 26\% dari siklus 1 ke siklus 2 .

\section{KESIMPULAN}

Model pembelajaran kooperatif tipe STAD dapat meningkatkan hasil belajar IPA siswa kelas IX. Adapun beberapa saran yang perlu dilakukan oleh seorang guru untuk meningkatkan kemampuannya dalam menggunakan pembelajaran kooperatif tipe STAD, diantaranya melakukan perencanaan dan persiapan pembelajaran sebelum melakukan pembelajaran, memberikan pelayanan kepada siswa secara optimal, menguasai materi pembelajaran dengan sebaik-baiknya, memberikan pelayanan secara personal atau klasikal secara terpadu, menggunakan alat peraga agar siswa tertarik dalam mengikuti proses pembelajaran, dan memberikan remedial dan pengayaan pembelajaran, serta mengaitkan pembelajaran dengan kehidupan siswa sehari-hari.

\section{DAFTAR PUSTAKA}

Hanafy. (2014). Konsep Belajar dan Pembelajaran. Lentera Pendidikan, 17 (1).

Prasetyowati, R. (2014). Pembelajaran IPA SMP Menurut Kurikulum 2013. Makalah PPM, 18.

Slavin, R.E. (2005). Cooperative Learning. Theory, research and practice (Cooperative Learning. Teori, Riset, dan Praktik). Terjemahan oleh Lita. 2009. Nusa Media. Bandung.

Sudana, I. P. A., \& Wesnawa, I. G. A. (2017). Penerapan Model Pembelajaran Kooperatif Tipe STAD Untuk Meningkatkan Hasil Belajar IPA. Jurnal Ilmiah Sekolah Dasar, 1(1), 1-8.

Vygotsky, L. S. (1978). Socio-cultural theory. Mind in society, 6, 52-58.

Wibawa, B. (2003). Penelitian Tindakan Kelas. Jakarta: Dirjen Dikdasmen. 
Jurnal Pendidikan Indonesia Gemilang, Vol 1, No.1, 2021, pp. 18-22

e-ISSN 27985091. DOI. 10.53889.jpig.v1i1.20

Widodo, W, F. Rachmadiarti, dan S.N Hidayati. (2017). Ilmu Pengetahuan Alam. Jakarta: Pusat Kurikulum dan Perbukuan, Balitbang, Kemendikbud

Wiriaatmadja, R. (2014). Metode Penelitian Tindakan Kelas. Bandung: PT Remaja Rosdakarya. 